\title{
Using Monte Carlo simulation to estimate natural groundwater recharge in Qatar
}

\author{
Husam Musa Baalousha ${ }^{1}$
}

Received: 13 May 2016/ Accepted: 21 May 2016/Published online: 8 June 2016

(C) Springer International Publishing Switzerland 2016

\begin{abstract}
Rainfall is the only source of groundwater recharge in arid countries, where no surface water exists. Quantification of the total volume of rainfall recharge is essential for water resources management, development and protection, but it is challenging. Numerous recharge estimation methods can be found in the literature, but the selection of the most appropriate one depends on the hydrogeological setting of the area of study and on the available data. Qatar is an arid country as rainfall is very little and surface water is non-existent. Aquifer is the only conventional source of water, which has been over-exploited in the last few decades. One of the main country's grand challenges is to implement an aquifer storage and recovery scheme, which requires understanding of the flow regime and quantification of the natural rainfall recharge. This study uses a water balance model coupled with Monte Carlo Simulation to quantify rainfall recharge. Using a historical groundwater piezometric map, the flow to the sea was calculated by applying Monte Carlo Simulation to the Darcy's Law. The natural recharge was calculated considering all water budget components. Results reveal the groundwater rainfall recharge amounts to 58.7 million $\mathrm{m}^{3}$, which is close to literature values obtained by other means.
\end{abstract}

Keywords Groundwater recharge - Stochastic water budget · Monte Carlo simulation · Qatar · Arid regions

Husam Musa Baalousha

baalousha@web.de

1 Qatar Environment and Energy Research Institute (QEERI), Hamad Bin Khalifa University (HBKU), PO Box: 5825, Doha, Qatar

\section{Introduction}

Groundwater recharge is the total volume of water that inflow into the saturated zone of the ground. This water may originate from different sources such as surface water bodies, rainfall, and lateral flow. In arid countries, recharge might occur only during wet seasons through rainfall. It is important to quantify recharge as it helps manage water resources in any catchment, and identify the safe yield of an aquifer. Recharge quantification is also influential for groundwater quality and aquifer vulnerability (Robins 1998). Many pollutants, especially those of anthropogenic origin resulted from human activities on-land, infiltrate the ground with the mobility of water and find their way into the sub-surface zone (Baalousha 2008). Several methods can be found in the literature discussing groundwater recharge estimation in arid and semi-arid areas. The selection of a method depends on the area of study as particular methods suit certain conditions, and each method has its limitation and strength. Xu and Kinzelbach et al. (2002) made an extensive survey of recharge estimation methods, with advantages and limitation of each. $\mathrm{Xu}$ and Beekman (2003) listed 16 methods of recharge estimation in arid and semi-arid regions, with a discussion of advantages and limitation of each, whereas Healy (2010) classified recharge methods into seven. In general, methods of recharge estimation can be divided into four categories covering surface water, unsaturated zone, saturated zone and a mix of saturated-unsaturated.

Isotopes analysis and water chemistry is one of the widely-used methods for identification of recharge areas and understanding of groundwater flow systems. Numerous studies have used isotopes such as tritium and Oxygen, in addition to noble gases and chlorofluorocarbons (CFC's) for water aging and identification of recharge origin 
(Yurtsever and Payne 1978; Nkotagu 1996; Alyamani 2001; Seiler and Gat 2007; Morgenstern et al. 2012; Prada et al. 2016). Isotopes methods are useful for identification of recharge source and for understanding water mixing processes in a catchment, but they provide little insight into the total volume of recharge into an aquifer.

Other recharge studies use hydrogeological settings, with the help of geographical information system (GIS) to delineate recharge areas and to identify potential artificial recharge zones (Chowdhury et al. 2010; Machiwal and Jha 2015; Baalousha 2015a; Yeh et al. 2016; Senanayakeet al 2016). Although these methods are good for delineation of recharge/discharge zones within a catchment, their main limitation is the uncertainty in quantification of the total recharge volume.

In addition to the methods mentioned above, recharge can directly be obtained using lysimeters (Brutsaert, 1982), which can provide precise measurements (Healy 2010). Several studies were based on lysimeters measurements for recharge estimation and understanding of flow drainage in the unsaturated zone (Chapman and Malone 2002; Freyberg et al. 2015; Duncan et al. 2016). The drawbacks of lysimeters are that they are expensive to install and need careful calibration. In addition, drainage measurements using lysimeters can be affected by near surface flow (Kinzelbach et al. 2002). Regional estimation of recharge using lysimeter can be difficult as the obtained values can vary from one point to another (Kinzelbach et al. 2002). While Duncan et al. (2016) found that lysimeters may over-estimate recharge values in the case of irrigated dry land, Chapman and Malone (2002) found them underestimate recharge.

In karst aquifers, analysis of springs outflow was used to estimate groundwater recharge (Hughes et al. 2008; Geyer et al. 2008). Other studies on karts are relied upon rainfallrunoff models to analyze recharge (Jukic and Denic-Juki 2009). The challenge facing the use of these methods in karst systems is that they require prior knowledge of conduit network (Hughes et al. 2008; Healy 2010). Tracersbased methods are more common for recharge estimation in karst aquifers as they produce more reliable results than rainfall-runoff methods (Greene 1997; Katz et al. 1997).

On a catchment scale level, water balance analysis is a simple method that has widely been used and applied to different study areas (Khazaei et al. 2003; Lee et al. 2006; Yeh et al. 2007; Baalousha 2007; Baalousha 2009a). In water balance models, recharge is calculated using all components of inflow and outflow into and out of a catchment. These components can be obtained using numerical models (Stoertz and Bradbury 1989; Dripps et al. 2006; Doble et al. 2008; Baalousha 2012a; b), but a good calibration is required to obtain reliable output (Kinzelbach et al. 2002). The advantage of water balance models is that they provide insight to the hydrological system and the interaction between recharge and other water budget component (Healy 2010). In addition to the catchment scale, water balance models can also be performed on boreholes in an aquifer using fluctuation of groundwater level, and its relation to rainfall. Examples of rainfall-water level methods are Cumulative Rainfall Departure (CRD) (Xu and van Tonder 2001; $\mathrm{Xu}$ and Beekman 2003; Baalousha 2005), Saturated Volume Fluctuation (SVF) and EARTH model (Beekman et al. 1996). However, these methods require a long time series to have a reliable estimate of recharge (Kinzelbach et al. 2002). The problem with water balance methods is the accuracy, which depends on the quality and quantity of data (Xu and Beekman 2003). Another limitation of water balance models is the assumption of a uniform recharge in the study area.

Uncertainty analysis has been widely used to overcome accuracy problems of water balance models. Stochastic methods such as Monte Carlo Simulation and Latin Hypercube Sampling were used in many studies in hydrogeology and recharge estimation (Bekesi and McConchie 1999; Hunt et al. 2001; Baalousha 2006; Dages et al. 2009; Baalousha 2009b; Zhen-min 2011; Baalousha 2015b). Monte Carlo Simulation and all sampling methods use the probability distribution of uncertain parameters to generate random samples repeatedly. The model is then solved for each realization to create a large number of model output, and the mean and standard deviation are calculated based on the outcome of all runs. According to the law of large numbers, the mean value from a large number of realizations should be close to the expected value.

This study develops a stochastic water balance model using Monte Carlo Simulation to estimate natural groundwater recharge for Qatar. The model considers all components of inflow and outflow into the aquifer and applies MCS on uncertain parameters. Results obtained, using this method, are compared to the ones in the literature.

\section{Methodology}

Figure 1 shows the stepwise methodology of recharge analysis using water balance model coupled with Monte Carlo Simulation. As described in the study area, the country of Qatar is surrounded by the sea from all directions but the south. Hence, the sources of recharge are rainfall and lateral groundwater flow across the southern border. The lateral groundwater flow across the border with Saudi Arabia is estimated at 2.2 million $\mathrm{m}^{3}$ per year (Food and Agriculture Organisation of the United Nations (FAO) 2016). As the country is a peninsula surrounded by sea, outflow occurs in a form of groundwater abstraction and 


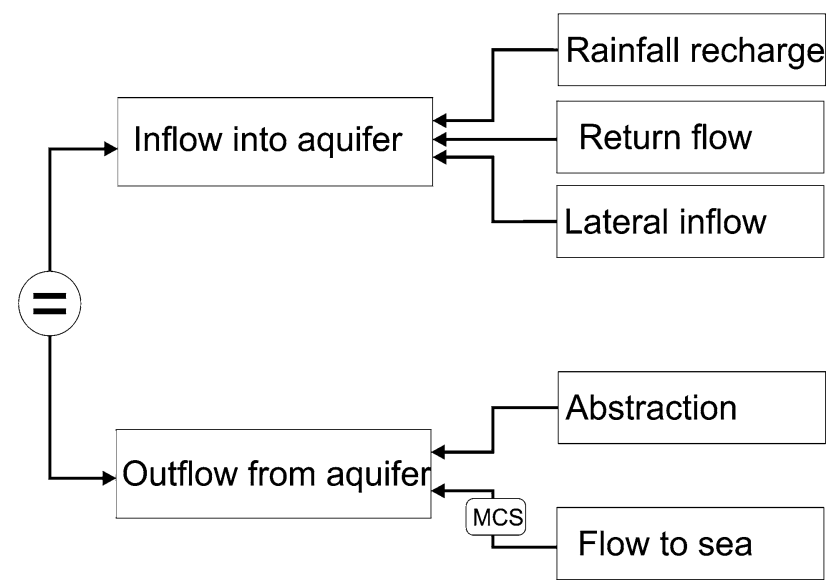

Fig. 1 Stepwise methodology of the water balance model for Qatar

flow to sea. In steady-state conditions, inflow to the aquifer equals outflow; that is:

$R+F_{L}+I_{R}=P+F_{S}$,

where $R$ is rainfall recharge, $F_{L}$ is lateral flow, $I_{R}$ is irrigation return flow, $P$ is abstraction and $F_{S}$ is flow to the sea. Equation (1) can be re-written as:

$R=P+F_{S}-F_{L}-I_{R}$

The two unknowns in Eq. (2) are the flow to the sea $\left(F_{S}\right)$ and recharge $(R)$. To obtain recharge, flow to the sea $\left(F_{S}\right)$ will be calculated using Monte Carlo Simulation applied to Darcy's Law. The calculation of flow to sea is based on contour lines of piezometric survey and hydrogeological characteristics of the aquifer. Applying MCS to Darcy's Law parameters along the coastal contours enables the estimation of the total outflow to the sea.

\section{The study area}

Qatar is a small arid country located in the eastern side of the Arabian Peninsula and extending in the southnorth direction in the Arabian Gulf (Fig. 2). It has limited water resources as the average annual rainfall is only $80 \mathrm{~mm}$ per year (Eccleston et al. 1981; Alsharhan et al. 2001). Rainfall is very erratic and occurs between November and March. The country is around $180 \mathrm{~km}$ long, and its maximum width is $85 \mathrm{~km}$; thus the total area of Qatar is $11600 \mathrm{~km}^{2}$ (Kimrey 1985). The terrain of Qatar is flat as the land surface elevation varies between 0 near the shoreline and a maximum of 107 meters above mean sea level at some locations in the southern part of the country.

Qatar topography is characterized by land depression originated as a result of land collapse because of limestone dissolution, forming karst features. These

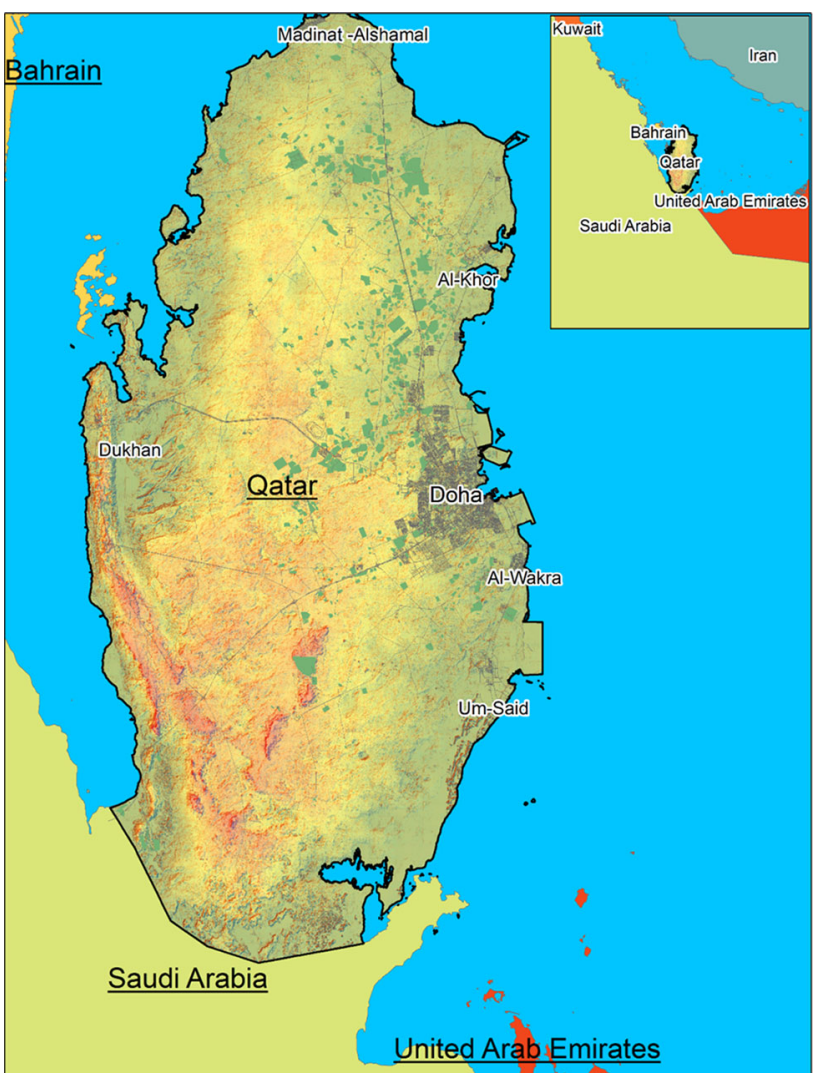

Fig. 2 The study area (Baalousha 2016)

depressions are good for recharging the aquifer, as runoff accumulates in these depressions (Vecchioli 1976, Kimrey 1985).

Qatar hydrogeology comprises geological formations from Pliocene and Eocene age, with some Quaternary deposits near the coastline, in a form of salt-flats or Sabkha (Al-Yousef 2003). Three water-bearing layers exist in Qatar: (1) The Dam and Dammam Formation on the top, which covers most of the surface area of Qatar; (2) Rus Formation underneath; and (3) Umm er Radhuma Formation in the bottom. All these three formations are composed of limestone with different degrees of dolomite, clay and chalk. The top layer (Dam and Dammam Formation) has a maximum thickness of 50 meters and is generally dry except in low land and near the coastline, whereas the underneath Rus formation is the main aquifer, especially in the northern part of the country. The thickness of Rus Formation varies between 30 and $90 \mathrm{~m}$ (Kimrey 1985). This layer contains gypsum and anhydrite in the southern part of the country, making the groundwater quality poor. The bottom layer has a thickness of around $300 \mathrm{~m}$ (Kimrey 1985), and extends from the eastern side of Saudi Arabia eastward covering the entire region. The quality of groundwater in this layer varies from one location to another, but in Qatar, it is generally saline. 


\section{Water balance}

Groundwater development started in the early 1950s using hand dug well, and the abstracted volume was small as the population of Qatar was 40,000 at that time (Al-Mohannadi et al. 2003). No records are available on the total volume of abstracted groundwater, but several reports indicated it was 50 million $\mathrm{m}^{3}$ in early seventies and increased to 60 million $\mathrm{m}^{3}$ per year in 1980 (Al-Mohannadi 2006; Schlumberger Water Services 2009). Irrigation return flow at that time is reported to be $20 \%$ of abstraction (Al-Kaabi, 1987).

Figure 3 shows the peizometric contour map for Qatar and flow direction based on data from 1980 (Al Hajari 1990). This map shows the water level has a peak high of 6 meters above mean sea level in the northern part of the country and declines to 0 near the coast. The flow is obviously from the middle of the peaks towards the sea and shallow areas like Sabkhas.

Groundwater flow to the sea and to coastal salt-flat (i.e. Dukhan Sabkha) occurs along the coastline, as shown in Fig. 3, which is indicated by a blue line in Fig. 4. The dotted line in Figs. 3 and 4 shows the limit of aquifer boundaries at the west. The total flow across the coastal line is calculated using Monte Carlo Simulation, as it is explained in the next section.

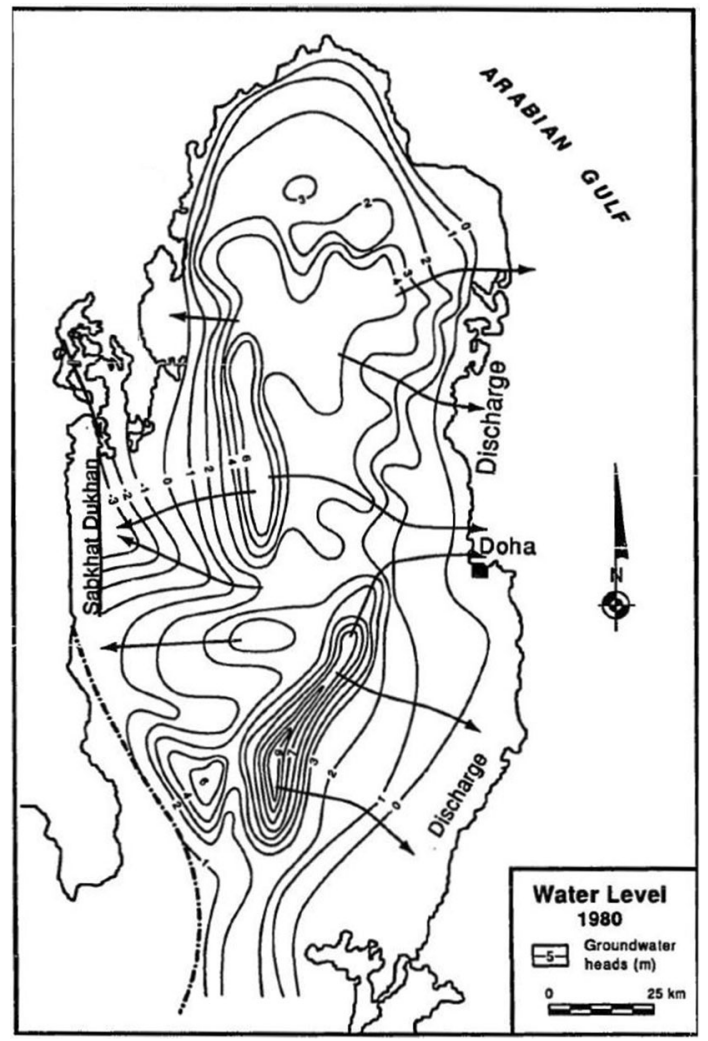

Fig. 3 Piezometric map and flow directions of the shallow aquifer in 1980 (Al Hajari 1990)

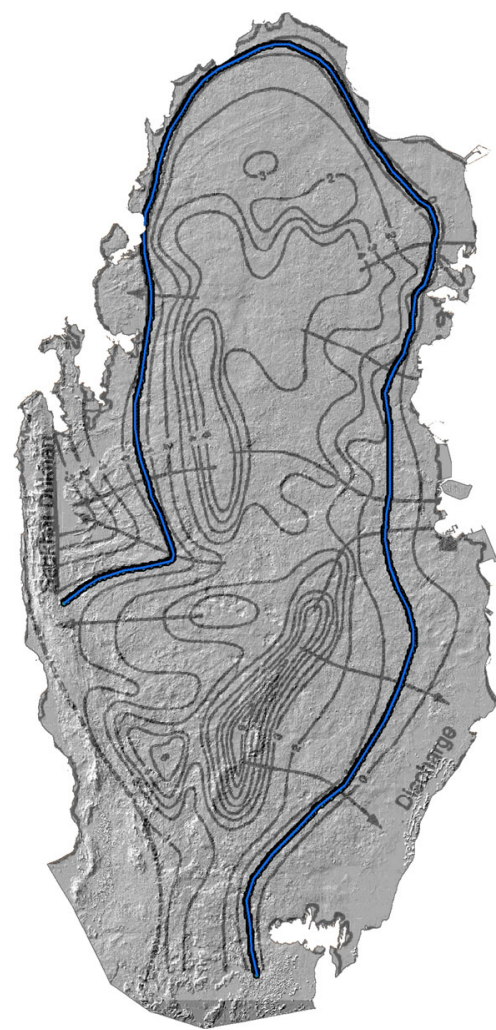

Fig. 4 Aquifer outflow to the sea and to salt-flats

\section{Monte Carlo simulation}

Flow to the sea (discharge) across the blue line in Fig. 4 can be computed using Darcy's Law as follows:

$F_{S}=L T \frac{\mathrm{d} h}{\mathrm{~d} n}$

where $L$ is the length of the counter across which the flow occurs, $T$ is the aquifer transmissivity, and $\mathrm{dh} / \mathrm{dn}$ is the flow gradient perpendicular to the contour. Using GIS, the flow gradient was calculated based on the coastal contours. Values of transmissivity were obtained from pumping test data (Eccleston et al. 1981; Schlumberger Water Services 2009). Table 1 shows the descriptive statics of the randomized parameters used in Darcy's Law. The total length across which the flow occurs (Fig. 4) is 327295 meters, and the flow gradient was calculated using Spatial Analyst tool in ArcGIS by creating a raster slope map from contours.

The Monte Carlo Simulation was implemented using parameters in Table 1 . The probability distribution was assumed to be log-normal to exclude negative values (Helsel and Hirsch, 2002). Fifteen million realizations were created for $\mathrm{T}$ and $\mathrm{dh} / \mathrm{dn}$ and the mean values of all realizations were used to calculate $F_{S}$ using Eq. (3). The expected value of flow to the sea $F_{S}$ is given by: 
Table 1 Descriptive statistics of flow parameters

\begin{tabular}{lllcc}
\hline Parameter & Min & Max & Mean & Standard deviation \\
\hline Transmissivity (T) $\left[\mathrm{m}^{2} /\right.$ day $]$ & 2 & 714 & 139.75 & 154.11 \\
Flow gradient & 0.000205 & 0.013752 & 0.00333 & 0.004582 \\
\hline
\end{tabular}

Table 2 Water balance components in 1980

\begin{tabular}{lc}
\hline Component & Value $\left(\right.$ million $\left.\mathrm{m}^{3}\right)$ \\
\hline Irrigation return flow (in) & 12 \\
Lateral groundwater inflow (in) & 2.2 \\
Recharge (in) & 58.73 \\
Groundwater abstraction (out) & -60 \\
Flow to the sea (out) & -12.93 \\
Total & 0.0 \\
\hline
\end{tabular}

$E\left(F_{S}\right)=\mu_{M C}=\frac{1}{n} \sum_{i=1}^{n} L\left(T \frac{\mathrm{d} h}{\mathrm{~d} n}\right)_{i}$

where $\mu_{M C}$ is the mean value of Monte Carlo and $n$ is the number of realizations. The variance of Monte Carlo estimation is:

$\sigma_{M C}^{2}=\frac{1}{n} \sum_{i=1}^{n} L\left(T \frac{\mathrm{d} h}{\mathrm{~d} n}-\mu_{M C}\right)^{2}$

Using Eqs. (4) and (5), the total mean annual flow to the sea, and its variance were found to be 12.93 million $\mathrm{m}^{3}$ and 0.42 million $\mathrm{m}^{3}$ per year, respectively. Applying these values to Eq. (2), recharge $(R)$ equals 58.73 million $\mathrm{m}^{3}$ per year.

Table 2 shows the components of water balance based on 1980. Negative values indicate the flow is out of the aquifer, whereas positive values mean inflow.

\section{Results and discussion}

Several studies have been done to estimate groundwater recharge in Qatar, as listed in Table 3. The wide range of recharge estimation reflects the high variability of rainfall from one year to another, in addition to differences in the outcome of each method. For example, Harhash and Yousif (1985) estimated recharge to be 21 million $\mathrm{m}^{3}$ in a dry year and 166 million $\mathrm{m}^{3}$ in a wet year. Schlumberger Water Services (2009) listed the estimate of groundwater recharge for the years from 1971 to 2005 , collected from different sources. The recharge values for this period vary between 22 and 162 million $\mathrm{m}^{3}$ per annum.

Result of this study is consistent and within the range of all previous studies. It is close to the one included in Food and Agriculture Organisation of the United Nations (FAO) (2016). Given the high variability of rainfall, the results of this study represent the long-term average.

\section{Conclusions}

Rainfall recharge quantification is essential for water resources management, planning and development. Due to scarcity of water, and in the light of Qatar National Vision for 2030 (Qatar General Secretariat for Development Planning, 2009), aquifer storage and recovery scheme has been identified as a means to increase the national water security. The first step towards aquifer storage and recovery implementation is to understand the flow regime and to quantify the natural groundwater recharge from rainfall.

Table 3 Estimates of groundwater recharge from different sources

\begin{tabular}{|c|c|c|}
\hline Method & $\begin{array}{l}\text { Recharge volume (million } \\
\mathrm{m}^{3} \text { ) }\end{array}$ & Reference \\
\hline SWAT2005 model & 66.6 & Schlumberger Water Services (2009) \\
\hline Water Balance for the year 1971-1983 & $21-166$ & Harhash and Yousif (1985) \\
\hline Groundwater flow model & 68 & Baalousha (2016) \\
\hline GIS analysis & 25.4 & Baalousha (2015a) \\
\hline Percentage of rainfall & 27 & Eccleston et al. (1981) \\
\hline $\begin{array}{l}\text { Water balance for the years } \\
\text { 1971-1974 }\end{array}$ & 20.9 & Parker and Pike (1976) \\
\hline Estimated from several sources & 56 & $\begin{array}{l}\text { Food and Agriculture Organisation of the United Nations (FAO) } \\
\text { (2016) }\end{array}$ \\
\hline Stochastic water balance & 58.73 & This study \\
\hline
\end{tabular}


Recharge estimation is very challenging as no particular method can be considered to be accurate, and every approach has its limitations. The selection of a recharge method may vary from one case to another depending on available data and hydrogeological characterization. The main drawback of most of the recharge estimation methods is the uncertainty of involved parameters in estimation. This study used Monte Carlo Simulation to overcome the uncertainty problem. The main advantage of the method used in this study is its low data requirement, and its suitability to Qatar hydrogeological setting. Being surrounded by the sea means the groundwater flow to the sea is the only outflow components, in steady-state conditions.

Monte Carlo Simulation was used to create random samples of aquifer transmissivity and head gradient. Darcy's Law was used to calculate the total groundwater influx to the sea. The estimated recharge in this study amounts to 85.73 million $\mathrm{m}^{3}$ per year, which is comparable to values in the literature obtained by other means.

\section{References}

Al Hajari SA (1990) Geology of the Tertiary and its influence on the aquifer system of Qatar and eastern Arabia. Ph.D. Thesis, Department of Geological Sciences, University of South Carolina, p 246

Al-Kaabi ZH (1987) The determinants of the future of agriculture in Qatar, Durham theses, Durham University. Available at Durham E-Theses Online: http://etheses.dur.ac.uk/6677/

Al-Mohannadi HI (2006) Depletion of groundwater resources in Qatar. Araa 22:48-51 (in Arabic)

Al-Mohannadi HI, Hunt CO, Wood AP (2003) Controlling residential water demand in Qatar: an assessment. Ambio 32:362-366

Alsharhan AS, Rizk ZA, Nairn AEM, Bakhit DW, Alhajari SA (2001) Hydrogeology of an arid region: the Arabian Gulf and adjoining areas. Elsevier

Alyamani M (2001) Isotopic composition of rainfall and groundwater recharge in the western province of Saudi Arabia. J Arid Environ 49:751-760

Al-Yousef, Mariam (2003) Mineralogy, geochemistry and origin of quaternary sabkhas in the Qatar peninsula, Arabian Gulf; 437 pages. PhD Thesis, University of Southampton

Baalousha $\mathrm{H}$ (2005) Using CRD method for quantification of groundwater recharge in the Gaza Strip, Palestine. Environ Geol 48(7):889-900

Baalousha H (2006) Groundwater pollution risk using a modified Latin hypercube sampling. J Hydroinf 8(3):223-234

Baalousha H (2007) Water balance model for Ruataniwha Basin. Hawke's Bay Regional Council, Napier, New Zealand.

Baalousha H (2008) Analysis of nitrate occurrence and distribution in groundwater in the Gaza Strip using major ion chemistry. Glob NEST J 10:337-349

Baalousha H (2009a) Stochastic water balance model for rainfall recharge quantification in Ruataniwha Basin, New Zealand. Environ Geol 58(1):85-93

Baalousha H (2009b) Using orthogonal array sampling to cope with uncertainty in ground water problems. Ground Water 47(5):709-713

Baalousha HM (2012a) Characterisation of groundwater-surfacewater interaction using field measurements and numerical modelling: a case study from the Ruataniwha Basin, Hawke's Bay, New Zealand. Applied Water Science. June 2012, Volume 2, Issue 2, pp 109-118

Baalousha HM (2012b) Modelling surface-groundwater interaction in the Ruataniwha basin, Hawke's Bay, New Zealand. Environ Earth Sci 66(1):285-294

Baalousha H (2015a) Estimation of natural groundwater recharge in Qatar using GIS. In: Weber T, McPhee MJ, Anderssen RS (eds) MODSIM2015, 21st International Congress on Modelling and Simulation. Modelling and Simulation Society of Australia and New Zealand, December 2015, pp. 2026-2032. ISBN: 978-09872143-5-5. http://www.mssanz.org.au/modsim2015/L2/baa lousha.pdf

Baalousha HM (2015b) Approximation of the exponential integral (well function) using sampling methods. J Hydrol 523:278-282

Baalousha HM (2016) Development of a groundwater flow model for the highly parameterized Qatar aquifers. Model Earth Syst Environ. doi:10.1007/s40808-016-0124-8

Beekman HE, Gieske A, Selaolo ET (1996) GRES: groundwater recharge studies in Botswana 1987-1996. Botswana J Earth Sci III: $1-17$

Bekesi G, McConchie J (1999) Groundwater recharge modelling using the Monte Carlo technique, Manawatu region, New Zealand. J Hydrol 224:137-148

Brutsaert W (1982) Evaporation into the Atmosphere, history, and applications. D. Reidel Pub. Co, Dordrecht

Chapman TG, Malone RW (2002) Comparison of models for estimation of groundwater recharge, using data from a deep weighing lysimeter. Math Comput Simul 59:3-17

Chowdhury A, Jha MK, Chowdary VM (2010) Delineation of groundwater recharge zones and identification of artificial recharge sites in West Medinipur district, West Bengal, using RS, GIS and MCDM techniques. Environ Earth Sci 59:1209-1222

Dages C, Voltz M, Bsaibes A et al (2009) Estimating the role of a ditch network in groundwater recharge in a Mediterranean catchment using a water balance approach. J Hydrol 375:498-512

Doble RC, Simmons CT, Walker GR (2008) Using modflow 2000 to model ET and recharge for shallow ground water problems. Ground Water 47:129-135

Dripps WR, Hunt RJ, Anderson MP (2006) Estimating recharge rates with analytic element models and parameter estimation. Ground Water 44:47-55

Duncan MJ, Srinivasan MS, McMillan H (2016) Field measurement of groundwater recharge under irrigation inCanterbury, New Zealand, using drainage lysimeters. Agric Water Manag 166:17-32

Eccleston BL, Pike JG, Harhash I (1981) The water resources in Qatar and their development. Food and Agricultural Organization of the United Nations

Food and Agriculture Organisation of the United Nations (FAO) (2016). AQUASTAT global water information system. [http:// www.fao.org/nr/water/aquastat/data/wrs/readPdf.html?f=QATWRS_eng.pdf] last accessed March 2016

Geyer T, Birk S, Liedl R, Sauter M (2008) Quantification of temporal distribution of recharge in karst system from spring hydrograph. J Hydrol 348:452-463

Greene EA (1997) Tracing recharge from sinking streams over spatial dimensions of kilometers in a karst aquifer. Ground Water 35:898-904

Harhash IE, Yousif AM (1985) Groundwater recharge estimates for the period 1972-1983. Ministry of Industry and Agriculture, Department of Agricultural and Water Research, February 1985

Healy RW (2010) Estimating groundwater recharge. Cambridge University Press, Cambridge 257p 
Helsel DR, Hirsch RM (2002) Statistical methods in water resources. Chapter A3, US Geological survey. Book 4, Hydrologic Analysis and Interpretation, p 524

Hughes AG, Mansour MM, Robins NS (2008) Evaluation of distributed recharge in upland semi-arid karst system: the West Bank Mountain Aquifer, Middle East. Hydrogeol J 16:845-854

Hunt RJ, Steuer JJ, Mansor MTC, Bullen TD (2001) Delineating a recharge area for a spring using numerical modeling, Monte Carlo techniques, and geochemical investigation. Ground Water 2001(39):702-712

Jukic D, Denic-Juki V (2009) Groundwater balance estimation in karst by using a conceptual rainfall-runoff model. J Hydrol 373:302-315

Katz BG, Coplen TB, Bullen TD, Hal Davis J (1997) Use of chemical and isotopic tracers to characterize the interactions between ground water and surface water in mantled karst. Ground Water 35:1014-1028

Khazaei E, Spink AEF, Warner JW (2003) A catchment water balance model for estimating groundwater recharge in arid and semiarid regions of south-east Iran. Hydrogeol J 11:333-342

Kimrey J (1985) Proposed artificial recharge studies in northern Qatar. United States Department of the Interior Geological Survey. Open file report 85-343, 1985

Kinzelbach W, Aeschbach W, Alberich C, Goni IB, Beyerle U, Brunner P, Chiang W-H, Rueedi J, Zoellmann K (2002) A Survey of Methods for Groundwater Recharge in Arid and Semiarid regions. Early Warning and Assessment Report Series, UNEP/DEWA/RS.02-2. United Nations Environment Programme, Nairobi, Kenya. ISBN 92-80702131-3

Lee C, Chen W, Lee R (2006) Estimation of groundwater recharge using water balance coupled with base-flow-record estimation and stable-base-flow analysis. Environ Geol 51:73-82

Machiwal D, Jha MK (2015) GIS-based water balance modeling for estimating regional specific yield and distributed recharge in data-scarce hard-rock regions. J Hydro Environ Res 9:554-568

Nkotagu H (1996) Application of environmental isotopes to groundwater recharge studies in a semi-arid fractured crystalline basement area of Dodma, Tanzania. J Afr Earth Sc 22:443-457

Parker DH, Pike JG (1976) Groundwater resources in Qatar and their potential for development: United Nations Food and Agriculture Organization, Integrated water and land use project Tech. Note no. 34, p 32

Prada S, Cruz JV, Figueira C (2016) Using stable isotopes to characterize groundwater recharge sources in the volcanic island of Madeira, Portugal. J Hydrol 536:409-425

Qatar General Secretariat for Development Planning (2009). QATAR NATIONAL VISION 2030, advancing sustainable development
Qatar's second human development report, July 2009. Published by MZ \& Partners, Printed by Gulf Publishing and Printing Company

Robins NS (1998) Recharge: the key to groundwater pollution and aquifer vulnerability. In: Robins NS (ed.) Groundwater Pollution, Aquifer Recharge and Vulnerability. Geological Society, London, Special Publications, 130, 15

Schlumberger Water Services (2009) Studying and developing the natural and artificial recharge of the groundwater in aquifer in the State of Qatar

Seiler KP, Gat JR (2007) Groundwater recharge from run-off, infiltration, and percolation. Springer, The Netherlands. p 257

Senanayake IP, Dissanayake DMDOK, Mayadunna BB, Weerasekera WL (2016) An approach to delineate groundwater recharge potential sites in Ambalantota, Sri Lanka using GIS techniques. Geosci Front 7:115-124

Stoertz MW, Bradbury KR (1989) Mapping recharge areas using a ground-water flow model-a case study. Ground Water 27:220-228

Uwe Morgenstern U, Van der Raaij R, Baalousha H (2012) Groundwater flow pattern in the Ruataniwha Plains as derived from the isotope and chemistry signature of the water. GNS Science Report; (no.2012/23); Aug 2012; p 44

Vecchioli J (1976) Preliminary Evaluation of the Feasibility of Artificial Recharge in Northern Qatar. United States Geological Survey. Open File Report (76-540)

Von Freyberg J, Moeck C, Schirmer M (2015) Estimation of groundwater recharge and drought severity with varying model complexity. J Hydrol 527:844-857

Xu Y, Beekman HE (2003) Groundwater recharge estimation in Southern Africa. UNESCO IHP Series No. 64

$\mathrm{Xu}$ Y, van Tonder GJ (2001) Estimation of recharge using a revised CRD method. Water SA 27:341-344

Yeh H, Lee C, Chen J, Chen W (2007) Estimation of groundwater recharge using water balance model. Water Resour 34:153-162

Yeh H, Cheng Y, Hung-I, L., Lee, C. 2016. Mapping groundwater recharge potential zone using a GIS approach in Hualian River, Taiwan. Sustainable Environment Research. In Press

Yurtsever Y, Payne BR (1978) Application of environmental isotopes to groundwater investigations in Qatar. International symposium on isotope hydrology; Neuherberg/Muenchen, Germany, F.R; 19 - 23 Jun 1978; AED-CONF-78-239-010; IAEA-SM-228/24

Zhen-min Z (2011) Application of Monte Carlo Method in Recharge Calculation of Underground Water Resources. Procedia Eng 23:316-319 